\title{
Biosorption of Cadmium from Aqueous Solutions Using A local Fungus Aspergillus cristatus (Glaucus Group)
}

\author{
Sahar W. Hassan ${ }^{1}$ and Hala Y. El-Kassas ${ }^{2 *}$ \\ ${ }^{1}$ Microbiology Laboratory, ${ }^{2}$ Hydrobiology Laboratory - Marine Environmental Division National Institute of Oceanography \\ and Fisheries, Alexandria, Egypt. \\ Accepted 2 December, 2011
}

\begin{abstract}
Cadmium (Cd) (II) resistant strain of a marine fungus, named Aspergillus cristatus was isolated from heavy metals polluted area in the Mediterranean Sea, Alexandria, Egypt during autumn, 2009. It could tolerate up to $100 \mathrm{mg} \mathrm{l}^{-1}$. Optimization of culture conditions for production of fungal biomass fortifying maximum Cd (II) removal was done by applying Placket Burman experimental design. Under optimized culture conditions, metal uptake was $(82 \%)$ achieved in a medium predicted to contain $\left(\mathrm{gl}^{-1}\right):$ glucose, $^{2}$; yeast extract, $1 ; \mathrm{KH}_{2} \mathrm{PO}_{4}, 4.00 ;\left(\mathrm{NH}_{4}\right)_{2} \mathrm{SO}_{4}, 4 ; \mathrm{MgSO}_{4}, 0.75 ; \mathrm{CaCl}_{2} \mathrm{H}_{2} \mathrm{O}, 0.2$ and inoculums size, $6 \%$. A verification experiment was applied. Results show that the metal uptake increased by about 1.86 fold for optimized medium. The increase in the $\mathrm{pH}$ value from 3 to 6 led to an increase in the Cd (II) uptake which reached the maximum level at $\mathrm{pH} 6$. The biosorption equilibrium time was $4 \mathrm{~h}$. Sorption isotherms follow the typical Langmuir adsorption pattern. Living biomass was more efficient for Cd (II) uptake compared to its dried biomass. A successful trial showed good applicability of the marine fungal isolate to remove $98.1 \%$ of Cd (II), in the waste effluent of El- Nesr Varta Company for Batteries after $2 \mathrm{~h}$ of contact. The free living fungus succeeds to remove $\mathrm{Cd}$ (II) more than the luffa adsorbed fungal biomass from the waste effluent. These quantitative biosorption and accumulation capacities demonstrate the potential application of marine A. cristatus for the bioremediation of Cd (II) from water systems.
\end{abstract}

Key words: Aspergillus cristatus, cadmium, experimental design.

\section{INTRODUCTION}

The presence of heavy metals in aquatic environments is known to cause severe damage to aquatic life, and among the toxic heavy metals, mercury, lead and cadmium called the big three are in the lime light due to their major impact on the environment (Diels et al., 2002; Volesky, 1994). Discharges containing cadmium, in particular, are strictly controlled due to the highly toxic nature of this element and its tendency to accumulate in the tissues of living organisms (Tilaki et al., 2004). Cadmium is introduced into the bodies of water from smelting, metal, plating, cadmium nickel batteries,

\footnotetext{
*Corresponding author. E-mail: halayassin12@yahoo.com.
}

phosphate fertilizer, mining, pigments, alloy industries and sewage sludge). Removal of toxic heavy metals from industrial waste waters is essential from the stand point of environmental pollution control (Guangyu and Thiruvenkatachari, 2003; Say et al., 2003; Svecova et al., 2006).

Most of the heavy metal salts are soluble in water and form aqueous solutions and consequently cannot be separated by ordinary physical means of separation. The conventional treatment procedures used for removal of metals are uneconomical (Say et al., 2003). Therefore, there is a need for a rapid, economical and environmentally benign technology for the removal of metals from polluted environment. The ability of microorganisms to accumulate metal ions from aqueous solutions has been widely reported (Tangaromsuk et al., 2002; AL-Garni, 2005; Svecova et al., 2006; EL-Sherif et 
al., 2008; Zamil et al., 2009).

Recent effective treatment to remove heavy metals in aqueous media involve the use of microorganisms (Yan and Viraraghavan, 2003; Wang and Chen, 2006, 2009; Igwe and Abia, 2006). Attention has been focused lately on the application of fungal species for metal removal from aqueous media (Huang and Huang, 1996; Wang and Chen, 2006; Vala, 2010). Fungi can accumulate metal by physico-chemical and biological mechanisms (Vankar and Bajpa, 2008; Volesky and May-Phillips, 1995). Fungal cells, both living and dead such as Aspergillus, Penicillium, Rhizopus, and Saccharomyces have been applied to metal removal from aqueous streams using either batch or continuous modes (Rostami and Joodaki, 2002; Kapoor and Viraraghavan, 1995; Park et al., 2005) and the use of dead cells seems to be more advantageous than using living cells (Gadd, 1992; Al-Garni et al., 2009).

The objective of the present work was to elucidate the capability of fungi isolated from polluted spot of the Mediterranean, Alexandria, Egypt to tolerate and biosorb cadmium. The most potent metal resistant local marine fungus was identified to the species level as Aspergillus cristatus. The work extended to optimization of culture conditions and finally uses the fungal cells (free living and dead) for the removal of $\mathrm{Cd}$ (II) from batteries waste effluent.

\section{MATERIALS AND METHODS}

\section{Screening for biosorption capability of the isolated fungi}

Different marine fungal isolates were isolated from polluted sea sediments (Eastern Harbor), Alexandria, Egypt during autumn 2009. A standard volume of sea water was added to Petridishes containing glucose peptone agar medium supplemented with different concentrations of $\mathrm{Cd}$ (II) solution. The fungal isolate which resists the highest concentration $\left(100 \mathrm{mg} \mathrm{I}^{-1}\right.$ ) was picked up, purified and used during the study.

\section{Identification of the isolated fungus}

The most promising marine fungal isolate showing maximum $\mathrm{Cd}$ (II) removal was selected and identified to the species level at the Regional Center for Mycology and Biotechnology (RCMB), Al-Azhar University, Cairo, Egypt, and by using the most documented keys in fungal identification (Raper and Fennell, 1965;; Watanabe, 2002). Through the study period, the organism was routinely maintained at $4^{\circ} \mathrm{C}$ on the mineral salts agar slants supplemented with $2 \%$ glucose.

\section{Scanning electron microscopy}

The fungal isolate was grown on malt extract agar (MEA) medium as a control and on mineral salts medium (MSM) amended with 100 $\mathrm{mgl}^{-1}$ of $\mathrm{Cd}$ (II) (treated). It was prepared for fixation and dehydration procedures at RCMB according to Bozzola and Russell (1999). The samples were dried completely in a critical point dryer and finally coated with gold in SPI-MODULE sputter coater. Then the specimens were viewed with a JEOL-JSM 5500LV.

\section{Metal solution}

A stock cadmium ion solution (1000 $\mathrm{mg} \mathrm{I}^{-1}$ ) was prepared by dissolving cadmium nitrate (Fisher Scientific Ltd) in deionized distilled water, shaking for $15 \mathrm{~min}$ at $100 \mathrm{rpm}$ and then left to stand for $24 \mathrm{~h}$ to obtain complete dissolution. Stock solution was diluted with deionized distilled water to obtain the necessary concentrations (Budavari et al., 1989). Solutions were adjusted to the desired $\mathrm{pH}$ values using $0.1 \mathrm{~N} \mathrm{NaOH}$ and $0.1 \mathrm{~N} \mathrm{HNO}_{3}$. The cadmium concentration was determined with an atomic absorption spectrophotometer (Unicam 929AA).

\section{Plackett-Burman experimental design}

To approach a near optimal response region of the medium composition to obtain the most factors affecting the fungal mat availability, a fractional factorial Plackett-Burman design based on the first-order model: $Y=B_{0}+B_{i} x_{i}$ was applied (Plackett and Burman, 1946). In this experiment, seven independent variables were screened in 12 combinations organized according to the Plackett - Burman matrix. Each variable can be at a high level (+), and a low level (-). Trials were performed in duplicates and the average of biomass production results was treated as the response. Actual values and coded levels of the variables investigated in this study are given in Tables 1 and 2, respectively.

\section{Effect of $\mathrm{pH}$}

Adsorption of metal ions by living biomass was studied at $\mathrm{pH}$ values 3, 4, 5, 6, 7 and 8. A fixed biomass of $400 \mathrm{mg} \mathrm{l}^{-1}$ was added to 100 $\mathrm{ml}$ of $\mathrm{Cd}$ (II) solution at an initial concentration of $100 \mathrm{mg} \mathrm{I}^{-1}$ for 120 min. To avoid shifts in $\mathrm{pH}$ due to biomass addition, the $\mathrm{pH}$ was adjusted with $0.1 \mathrm{~N} \mathrm{HCl}$ or $1 \mathrm{~N} \mathrm{NaOH}$ after the solution had been in contact with the fungal biomass. Triplicate samples were analyzed as above.

\section{Effect of contact time}

To determine the optimal contact time, a fixed adsorbent concentration of $400 \mathrm{mg} \mathrm{l}^{-1}$ of fungal biomass was added to $100 \mathrm{ml}$ of aqueous solution containing an initial metal concentration of 100 $\mathrm{mg} \mathrm{I}^{-1}$ of $\mathrm{Cd}$ (II). Three samples were taken for 30, 60, 90 120, 150, 180, 210, 240 and 270 min and measured as above.

\section{Metal biosorption mechanism}

A batch equilibrium method was used to determine sorption of cadmium by the tested fungus. All biosorption experiments were conducted in $250 \mathrm{ml}$ Erlenmeyer flasks containing $100 \mathrm{ml}$ of the tested cadmium solution. A fixed weight of fungal biomass was exposed to metal solution at $25 \pm 2^{\circ} \mathrm{C}$ on a rotary shaker $120 \mathrm{rpm}$. The biomass was separated by centrifugation at $10000 \mathrm{rpm}$ for 10 min and residual cadmium concentration was measured in the supernatant. Metal adsorbed by the biomass (mg metal/g biomass) was calculated (Volesky and May-Phillips, 1995) as:

$$
\mathrm{Q}=\mathrm{V}\left(\mathrm{Ci}-\mathrm{C}_{\mathrm{e}}\right) / \mathrm{M}
$$

Where, $\mathrm{Q}=$ cadmium uptake ( $\mathrm{mg} \mathrm{Cd} / \mathrm{mg}$ biomass), $\mathrm{V}=$ volume of cadmium suspension (ml), Ci = initial Cd (II) concentration ( $\left.\mathrm{mg} \mathrm{I}^{-1}\right)$, $\mathrm{C}_{\mathrm{e}}=$ final $\mathrm{Cd}$ (II) concentration $\left(\mathrm{mg} \mathrm{I}^{-1}\right), \mathrm{M}=$ weight of biosorbent (mg). 
Table 1. The Plackett-Burman experimental design matrix.

\begin{tabular}{llll}
\hline Variable & Level $\mathbf{0}$ & & \\
\hline Glucose & 5 & 10 & 15 \\
$\left(\mathrm{NH}_{4}\right)_{2}\left(\mathrm{SO}_{4}\right)$ & 1.0 & 2.5 & 4.0 \\
Yeast extract & 1.0 & 2.5 & 4.0 \\
$\mathrm{KH}_{2} \mathrm{PO}_{4}$ & 1.0 & 2.5 & 4.0 \\
$\mathrm{MgSO}_{4} .7 \mathrm{H}_{2} \mathrm{O}$ & 0.25 & 0.5 & 0.75 \\
$\mathrm{CaCl}_{2} . \mathrm{H}_{2} \mathrm{O}$ & 0.06 & 0.13 & 0.2 \\
Inoculum size & $2 \%$ & $4 \%$ & $6 \%$ \\
\hline
\end{tabular}

The actual values for screening medium compositions $\left(\mathrm{gl}^{-1}\right)$ for cadmium uptake by marine $A$. cristatus: glucose, $\mathrm{X}_{1} ;\left(\mathrm{NH}_{4}\right)_{2}\left(\mathrm{SO}_{4}\right), \mathrm{X}_{2}$; yeast extract, $\mathrm{X}_{3} ; \mathrm{KH}_{2} \mathrm{PO}_{4}, \mathrm{X}_{4} ; \mathrm{MgSO}_{4} .7 \mathrm{H}_{2} \mathrm{O}, \mathrm{X}_{5} ; \mathrm{CaCl}_{2} . \mathrm{H}_{2} \mathrm{O}, \mathrm{X}_{6} ;$ Inoculums' size (\%), $\mathrm{X}_{7}$.

Table 2. The coded levels of the medium components and the experimental results of the Plackett-Burman experimental design.

\begin{tabular}{lllllllll}
\hline Trial & $\mathbf{G}\left(\mathbf{X}_{1}\right)$ & $\mathbf{N}\left(\mathbf{X}_{2}\right)$ & $\mathbf{Y . E}\left(\mathbf{X}_{3}\right)$ & $\mathbf{K}\left(\mathbf{X}_{4}\right)$ & $\mathbf{M g}\left(\mathbf{X}_{5}\right)$ & $\mathbf{C a}\left(\mathbf{X}_{6}\right)$ & $\mathbf{I . S}\left(\mathbf{X}_{7}\right)$ & $\mathbf{C d}(\mathbf{I I})$ removal\% \\
\hline 1 & + & + & - & + & - & - & - & 34 \\
2 & - & - & - & + & + & + & - & 49 \\
3 & - & - & - & - & - & - & - & 24 \\
4 & + & + & + & - & + & + & - & 38 \\
5 & - & - & + & + & + & - & + & 56 \\
6 & + & - & + & - & - & - & + & 34 \\
7 & + & + & - & + & + & - & + & 68 \\
8 & - & + & + & + & - & + & + & 82 \\
9 & + & - & - & + & + & + & + & 49 \\
10 & - & + & + & - & + & - & - & 36 \\
11 & + & - & + & - & + & - & - & 34 \\
12 & - & + & - & - & - & + & + & 30 \\
13 & 0 & 0 & 0 & 0 & 0 & 0 & 0 & 44 \\
\hline
\end{tabular}

The sorption isotherm relationship can be expressed mathematically by plotting $q$ versus $C_{e}$. The linear form of Langmuir isotherm equation is represented by the equation:

$$
q=Q_{\max } b C_{e} / 1+b C_{e}
$$

where, $Q_{\max }$ is the maximum amount of metal per gram of biomass corresponding to saturation of the adsorbing sites. The dissociation constant (b) is a coefficient related to the affinity between the metals and biomass (El-Morsy, 2004).

Fourier Transform Infra Red Spectroscopy (FT- IR) of Cd (II) loaded fungal species

FT-IR was carried out as a tool to describe the fungal biosorbtion phenomenon using $\mathrm{Cd}$ (II) loaded fungal species. The fungal biomass was dried to almost nil moisture before and after biosorption and sent for FTIR analysis at the Faculty of Pharmacy, Alexandria University.

\section{Biosorption of Cd (II) by dried biomass}

A dried fungal biomass dispensed in $250 \mathrm{ml}$ Erlenmeyer flasks containing $100 \mathrm{mg} \mathrm{I}^{-1}$ of deionized distilled water was shaked at 120 rpm for $120 \mathrm{~min}$, then the biomass was removed by centrifugation and the residual cadmium concentration was measured in the filtrate.

\section{Biosorption of Cd (II) by immobilized biomass}

The spore suspension $(0.5 \mathrm{ml})$ was inoculated into $250 \mathrm{ml}$ Erlenmeyer flasks containing $100 \mathrm{ml}$ of the optimized growth medium and pre-weighed luffa discs as an immobilizing matrix. Culture flasks for free hyphal growth, with no luffa discs in the medium, served as the controls. The flasks were incubated at $35^{\circ} \mathrm{C}$ and shaken at $100 \mathrm{rpm}$. After eight days of incubation, both free and luffa immobilized biomass of $A$. cristatus were harvested from the medium, washed twice with deionized water and then used for biosorption of Cd (II) solution as was described previously (lqbal et al., 2007).

\section{Biosorption of Cd (II) in the final waste effluents of El-Nesr Varta Company for Batteries using marine A. cristatus}

The applicability of the marine A. cristatus to take up Cd (II) in an industrial waste was tested. Samples of the final waste effluent of $\mathrm{El}$ Nesr Varta Company for Batteries were collected from the region of waste discharge at the sea shore. The experiments were conducted 


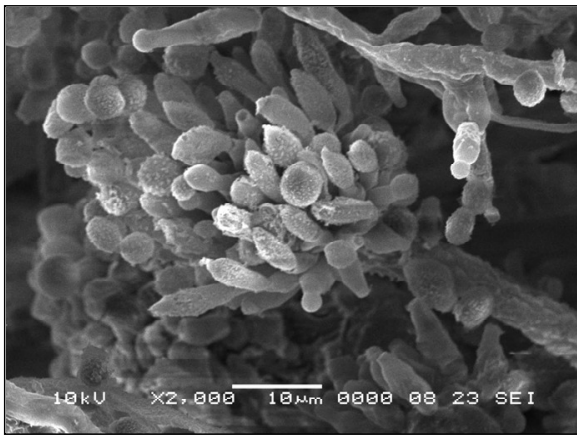

A

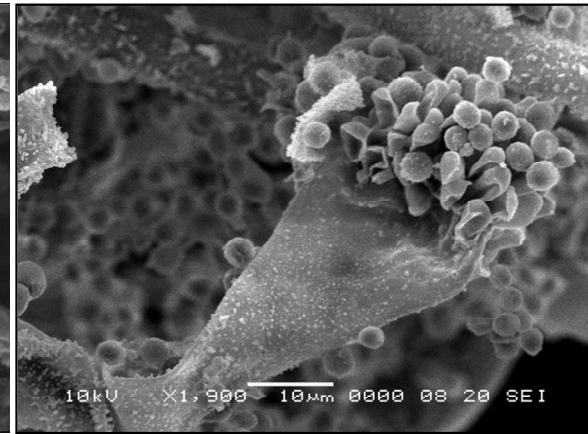

B

Figure 1. Scanning electron micrographs of marine $A$. cristatus. $\mathrm{A}$, control conidia and hyphae; $\mathrm{B}$, conidia and hyphae exposed to $100 \mathrm{mgl}^{-1}$ of $\mathrm{Cd}$ (II) for $2 \mathrm{~h}$.

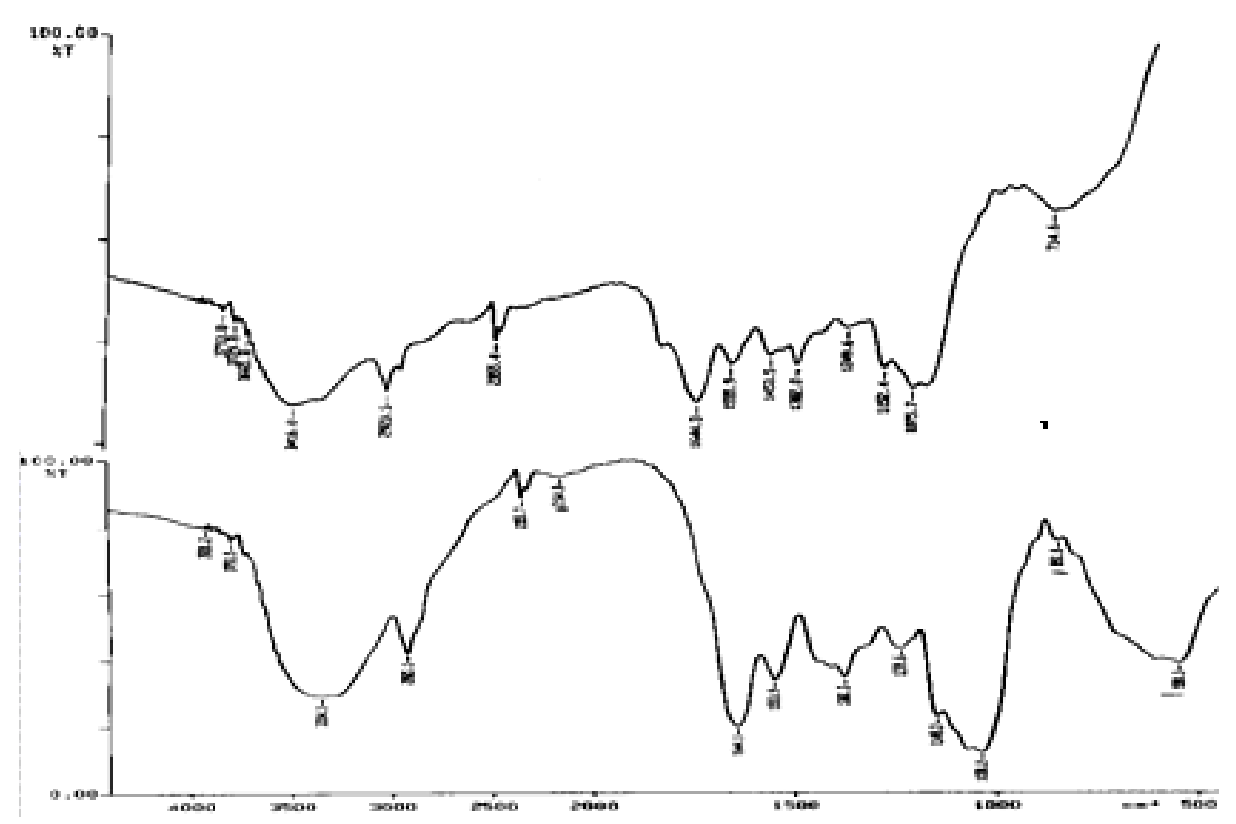

Figure 2. FTIR spectra of marine $A$. cristatus, a, upper curve (before exposure to cadmium) and $b$, lower curve [after exposure to $\mathrm{Cd}(\mathrm{II})$ ].

as previously described using fungal mate, incubated in a rotary shaker at $150 \mathrm{rpm}$ and maintained at ambient temperatures (28 to $\left.30^{\circ} \mathrm{C}\right)$.

\section{RESULTS}

\section{Screening for Cd (II) removal efficiency}

In this study, several marine fungal isolates were submitted to a preliminary experiment to screen their efficiency for $\mathrm{Cd}$ (II) resistance. One of the isolates named $A$. cristatus, was selected for further investigations. The selected fungus resisted the highest Cd (II) concentration (100 $\mathrm{mg} \mathrm{I}^{-1}$ ). Electron micrographs of the fungus before and after exposing to $\mathrm{Cd}$ (II) solution were presented (Figure 1).

\section{FTIR spectra of the fungus before and after exposure to cadmium}

FTIR spectrum of the fungus before exposure to Cd (II) exhibits a number of peaks in the range of 3614 to 3793 $\mathrm{cm}^{-1}$ associated with the stretching vibrations of the $\mathrm{OH}$ and $\mathrm{NH}$ groups (Figure 2a). The peak at $2923 \mathrm{~cm}^{-1}$ is assigned to the $\mathrm{C}-\mathrm{H}$ stretching vibration of $\mathrm{CH}_{3}$. The peak at $1644 \mathrm{~cm}^{-1}$ corresponds to the amide stretching vibration. The peak at $1453 \mathrm{~cm}^{-1}$ is ascribed to the 
Table 3. Statistical analysis of the Placket-Burman experimental design.

\begin{tabular}{lll}
\hline Variable & Main effect & t-value \\
\hline Glucose $\left(\mathrm{X}_{1}\right)$ & -11.5 & -0.50 \\
$\left(\mathrm{NH}_{4}\right)_{2}\left(\mathrm{SO}_{4}\right)\left(\mathrm{X}_{2}\right)$ & 7 & 1.05 \\
Yeast extract $\left(\mathrm{X}_{3}\right)$ & -1.66 & 0.65 \\
$\mathrm{KH}_{2} \mathrm{PO}_{4}\left(\mathrm{X}_{4}\right)$ & 18.66 & 2.80 \\
$\mathrm{MgSO}_{4} .7 \mathrm{H}_{2} \mathrm{O}\left(\mathrm{X}_{5}\right)$ & 9.66 & 1.45 \\
$\mathrm{CaCl}_{2} \mathrm{H}_{2} \mathrm{O}\left(\mathrm{X}_{6}\right)$ & 5 & 0.75 \\
Inoculum size $\left(\mathrm{X}_{7}\right)$ & 17.3 & 2.60 \\
\hline
\end{tabular}

$\mathrm{t}$-value significant at the $1 \%$ level $=3.70$. $\mathrm{t}$-value significant at the $5 \%$ level $=2.45$. Standard $t$-values are obtained from statistical methods (Cochran and Snedecor, 1989).

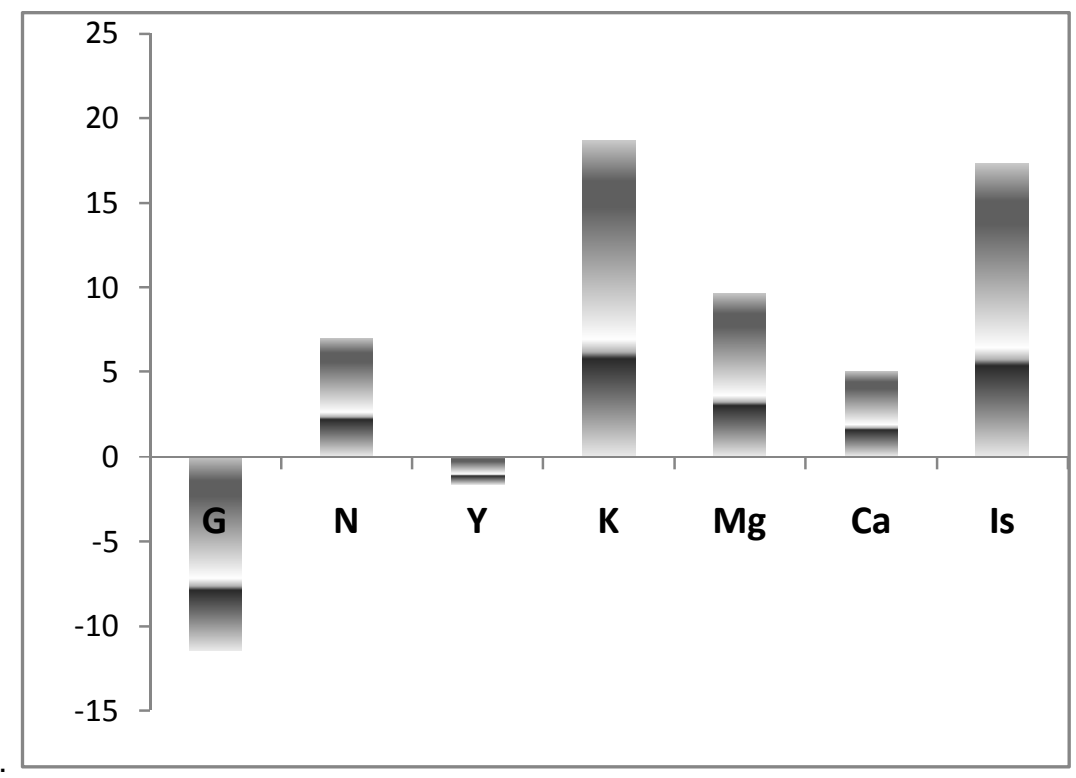

Figure 3. Elucidation of fermentation conditions affecting $\mathrm{Cd}$ (II) uptake by marine $A$. cristatus.

deformation of $\mathrm{C}-\mathrm{H}$ in $-\mathrm{CH}_{3}$ and $>\mathrm{CH}_{2}$ functional groups. The finger print region at 1000 to $1282 \mathrm{~cm}^{-1}$ includes bands due to $\mathrm{C}-\mathrm{O}$ of the polysaccharides found naturally in fungi. On the other hand, FTIR spectrum of the fungi loaded with cadmium (Figure 2b) showed a shift in band positions and a change in the intensity of the peaks.

\section{Optimization of culture conditions by applying Placket Burman experimental design}

The results (Table 2) show the coded levels of the medium components and the experimental results of the Plackett-Burman experimental design. All experiments were performed in duplicates and the average of results was recorded. Results show that the fungal mat produced during trial number eight exhibited the maximal $\mathrm{Cd}$ (II) uptake (82\%).
The main effects of each variable on the metal uptake as well as t-values were estimated as shown (Table 3 ) and graphically represented (Figure 3 ). Results indicate that the main factors that had negative effect on the metal uptake were glucose and yeast extract; where, high concentration of each in the medium caused a decrease in the metal uptake. On the other hand, $\mathrm{KH}_{2} \mathrm{PO}_{4}$, $\mathrm{MgSO}_{4} .7 \mathrm{H}_{2} \mathrm{O}, \quad\left(\mathrm{NH}_{4}\right)_{2} \mathrm{SO}_{4}, \mathrm{CaCl}_{2}$ and inoculums size exhibited positive effect on the metal uptake. Using high concentrations in the medium fortified the mass production of marine $A$. cristatus responsible for maximum metal uptake.

Statistical analysis (t-test) presented in Table 3 showed that $\mathrm{KH}_{2} \mathrm{PO}_{4}$ and inoculums size were the most significant factors affecting the metal uptake. The interacting effect of $\mathrm{KH}_{2} \mathrm{PO}_{4}$ with the inoculums size is described in three-dimensional representation (Figure 4). As illustrated, the high levels of both variables cause an 


\section{Surface Plot of Cd(II) removal\%o vs K(X4); I.S(X7)}

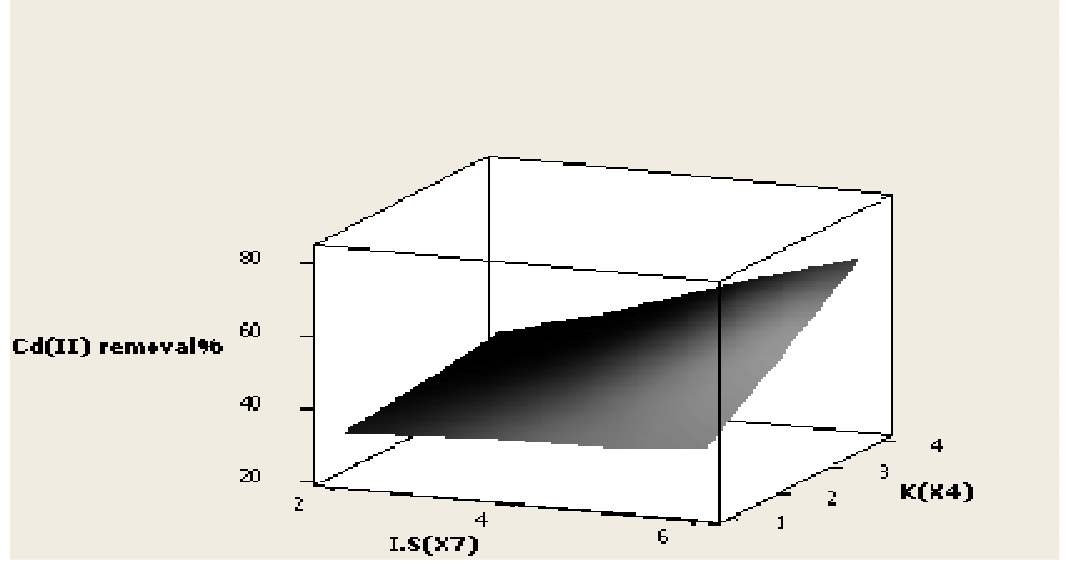

Figure 4. Interaction effect between $\mathrm{KH}_{2} \mathrm{PO}_{4}(\mathrm{~K})$ and inoculums size (I.S) on $\mathrm{Cd}$ (II) uptake (\%) by marine $A$. cristatus.

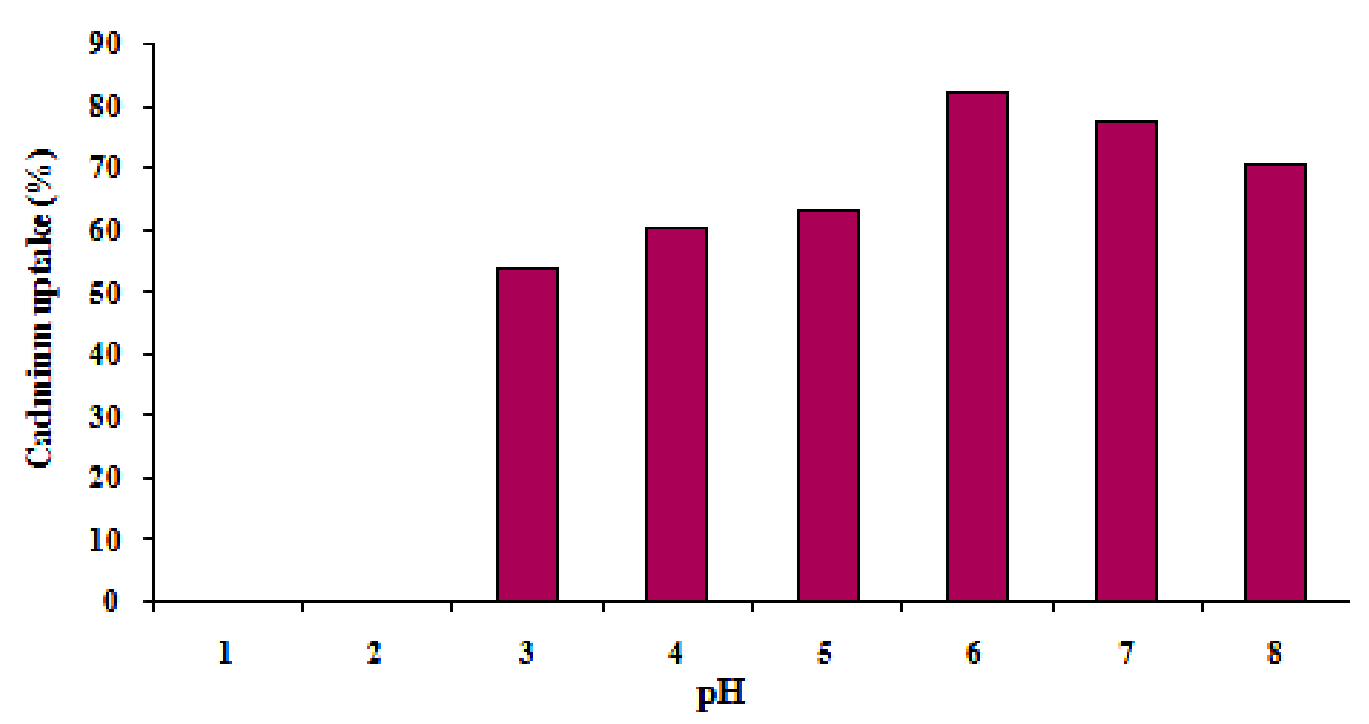

Figure 5. Effect of $\mathrm{pH}$ on $\mathrm{Cd}$ (II) uptake \% by marine $A$. cristatus.

increase in the cadmium uptake by $A$. cristatus.

Under optimized culture conditions, the highest percentage of metal uptake was (82\%) achieved in a medium predicted to contain $\left(\mathrm{gl}^{-1}\right)$ : glucose, 5; yeast extract, $1 ; \mathrm{KH}_{2} \mathrm{PO}_{4}, 4.00 ; \mathrm{NH}_{4}\left(\mathrm{SO}_{4}\right), 4 ; \mathrm{MgSO}_{4}, 0.75$; $\mathrm{CaCl}_{2} \cdot \mathrm{H}_{2} \mathrm{O}, 0.2$ and inoculum's size, 6\%. A verification experiment was applied to compare between the basal and optimized medium. Results show that on using the optimized medium, the metal uptake increased by about 1.861 fold.

\section{Influence of $\mathrm{pH}$ on metal biosorption by $A$. cristatus}

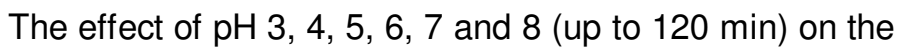

uptake of $\mathrm{Cd}$ (II) by marine $A$. cristatus is shown (Figure 5 ), which indicates that the more acidic $\mathrm{pH} 3$ was not favorable for $\mathrm{Cd}$ (II) ions uptake (53.7\%). On the other hand, $\mathrm{pH} 6$ is the most favorable where the fungal isolate succeeded to up take (82.3\%) of $\mathrm{Cd}$ (II). However, at $\mathrm{pH}$ 7 , the marine isolate exhibited biosorption activity up to (77.5\%).

Time-course profile of the Cd (II) removal efficiency by marine $A$. cristatus

As for the contact time of biosorbent at the $\mathrm{pH} 6$ with 100 $\mathrm{mg} \mathrm{Cd}(\mathrm{II}) / \mathrm{l}$, the data (Figure 6) revealed that the uptake efficiency increased with increasing the time. The 


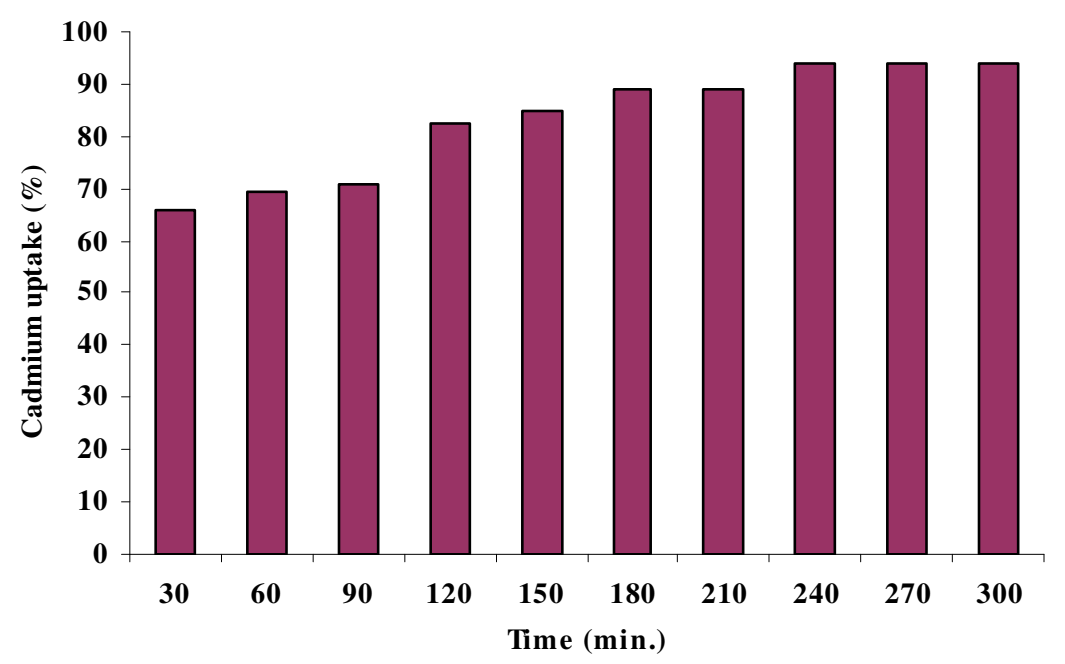

Figure 6. Effect of contact time on Cd (II) uptake \% by marine A. cristatus.

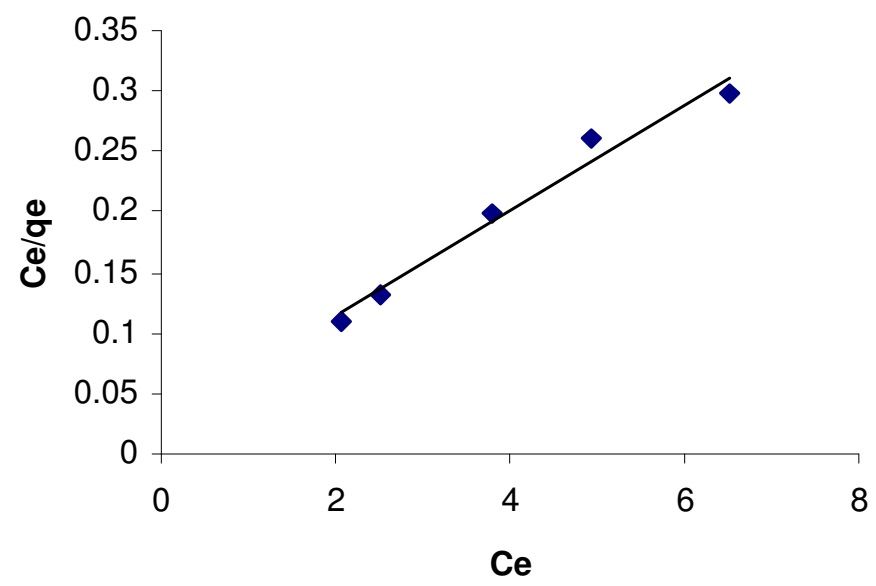

Figure 7. Langmuir isotherm of $\mathrm{Cd}$ (II) uptake by marine $A$. cristatus.

required time to attain equilibrium was $240 \mathrm{~min}$ and the maximum efficiency was $94 \%$.

\section{Biosorption mechanism}

Sorption isotherm was used to represent the distribution of metal ions between aqueous and solid phases. It is customary to determine metal uptake (q) by the biosorbent as the amount of metals bound by the unit of biomass. It is also possible to calculate the adsorption capacities and dissociation constants of metal ions. The linearity of the plots $C_{\mathrm{e}} / q_{\mathrm{e}}$ versus $C_{\mathrm{e}}$ (Figure 7 ) suggested the applicability of Langmuir isotherm for the present system. Values of Langmuir constants are shown (Table 4). As shown, the predicted $Q_{\max }$ was higher than the experimental one.

\section{Effect of immobilization on Cd (II) biosorption efficiency}

Immobilization of fungal biomass was carried out using luffa pulp as supporting material.

Results (Figure 8) show that no increase in the removal efficiency of Cd (II) by using the adsorbed biomass and the free biomass was superior to its immobilized biomass by about two fold.

\section{Effect of drying on Cd (II) biosorption efficiency}

Dried biomass was used to determine the efficiency of the fungus to biosorp cadmium. Results (Figure 8) show that biomass of the living $A$. cristatus was more efficient to biosorb $\mathrm{Cd}$ (II) than its dried biomass and no 
Table 4. Values of Langmuir constants during uptake of cadmium (II) by marine A. cristatus.

\begin{tabular}{ll}
\hline Constant & Value \\
\hline $\mathrm{Q}_{\max }$ & 23.26 \\
Dissociation constant (b) & 1.65 \\
Affinity $(\mathrm{C}=1 / \mathrm{b})$ & 0.6 \\
$\mathrm{R}^{2}$ & 0.976 \\
\hline
\end{tabular}

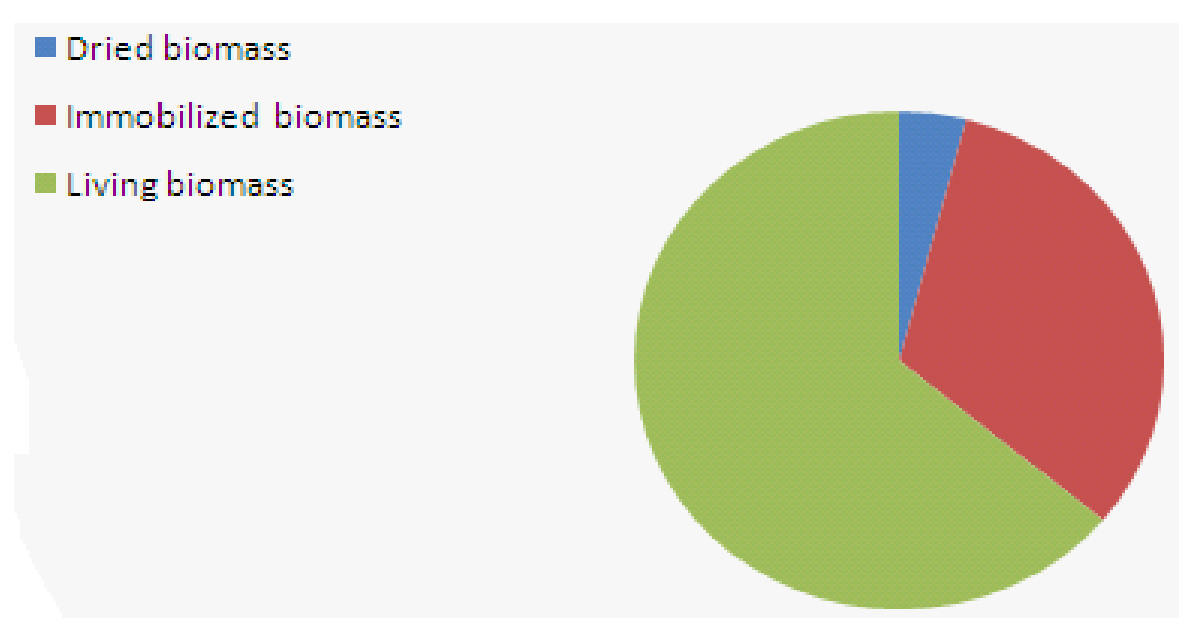

Figure 8. Cadmium biosorption by living and dried as well as immobilized biomass of marine $A$. cristatus.

relationship between the efficiency of living biomass and its corresponding dried biomass to absorb cadmium ions.

\section{Biosorption of cadmium from El - Nesr Varta battery waste effluent}

\section{Battery effluent quality}

The Cd (II) content of El - Nesr Varta battery waste effluent ranged between 100 and $130 \mathrm{mgl}^{-1}$. The $\mathrm{pH}$ of the effluent ranged from 3 to 6 . The source of $\mathrm{Cd}$ (II) was cadmium sulfate. The fungal isolate, $A$. cristatus was able to uptake cadmium with high efficiency reached to $98.1 \%$ after $2 \mathrm{~h}$ when exposed to batteries waste effluent (Figure 9).

\section{DISCUSSION}

Scanning electron micrographs showed the change in the fungal morphology after exposure to cadmium solution and was further ensured by FTIR spectrum. Numerous chemical functional groups such as carboxyl, hydroxyl, amide, ether, etc. have been identified as potential adsorption sites to be responsible for binding metallic ions to fungi. Their potential for metal uptake depends on factors such as the abundance of sites, their accessibility, chemical state and affinity between adsorption site and metal (Lodeiro, 2006).

The change in the position and intensity of the peaks especially in the region range 3200 to $3500 \mathrm{~cm}^{-1}$ can be attributed to complexation of the functional groups of the fungus, which resulted from hydrolyzing of some polysaccharides on the cell wall to shorter saccharides such as oligosaccharides, dioses and monoses.Similar results were obtained by (Rao et al., 2005 and Akthar et al., 1996).

Medium composition has a very remarkable effect on cell wall composition and consequently the cell affinity to specific metal cation (El-Helow et al., 2000). In favorable fermentation conditions, metal ions absorbing surfaces (groups) of the biosorbent will be excellent counter ions for the heavy metals forming more stable complexes (Akthar and Mohan, 1995).

Plackett-Burman design (Plackett and Burman, 1946) was employed to determine the nutritional requirements for metal uptake (Ghanem and Abou-Elela, 2006). In the present study, $\mathrm{KH}_{2} \mathrm{PO}_{4}$ and inoculums size were the most significant factors affecting cadmium uptake. Glucose exhibited negative effect on the metal uptake as was reported by El-Sersy and El-Sharouny (2007) conversely to them yeast extract had a negative effect on the cadmium uptake. On the other hand, high concentration 


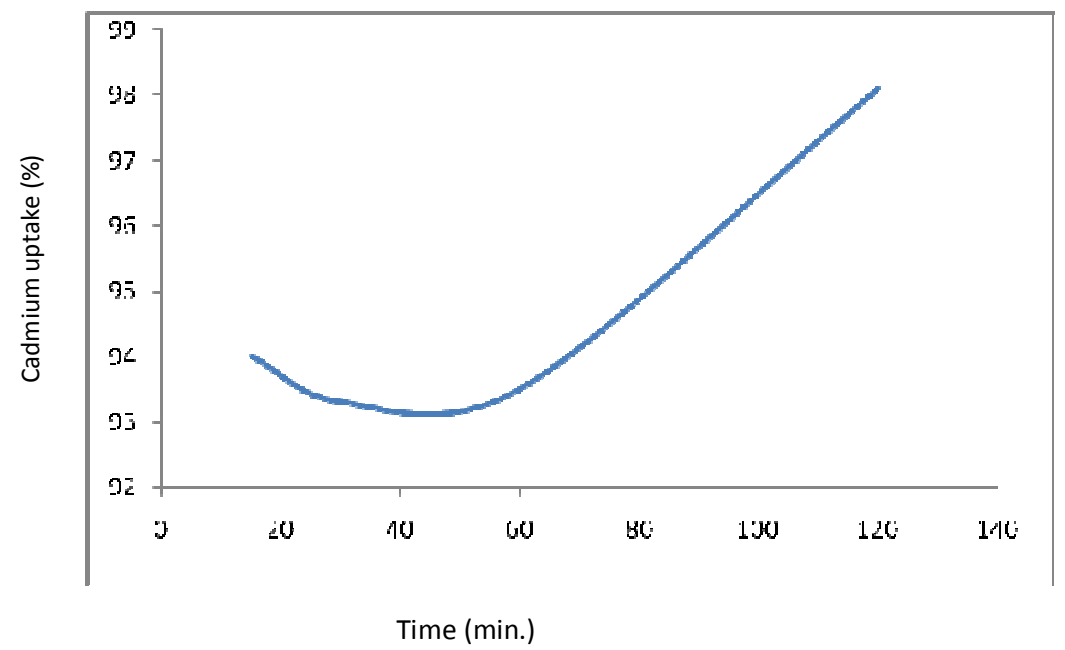

Figure 9. Cadmium uptake by marine $A$. cristatus from El -Nesr Varta batteries waste effluent.

of $\left(\mathrm{NH}_{4}\right)_{2}\left(\mathrm{SO}_{4}\right)$ and $\mathrm{Mg} \mathrm{SO}$ in the medium enhanced the metal uptake.

The $\mathrm{pH}$ value has an important role in metal ions biosorption where active biosorbing groups have the ability to accept or lose protons and depend mainly on the $\mathrm{pH}$ value (Pinghe et al., 1999; Yalcinkaya et al., 2002). The present study reports that increase in the $\mathrm{pH}$ value from 3 to 6 caused an increase in the cadmium uptake and it reached the maximum level at $\mathrm{pH} 6$ and reduced in higher $\mathrm{pH}$. This could be attributed to formation of soluble cadmium hydroxides/complexes (Kacar et al., 2000; Say et al., 2003; Svecova et al., 2006; Mashitah et al., 2008; Al Garni et al., 2009). Conversely, Singh et al. (2005) reported that the adsorption of cadmium was higher in alkaline $\mathrm{pH}$.

The optimal time for biosorption was $4 \mathrm{~h}$ after contact. Some other studies reported that most of the biosorbion was achieved in 5 to $15 \mathrm{~min}$. The fluctuation of equilibrium period was recorded by many workers and depended in many factors of which the type and nature of the biomass, $\mathrm{pH}$, metal ions, and physicochemical properties of the biosorption process (Saglam et al., 1999; Kacar et al., 2000; Abu Al-Rub et al., 2004; Herrero et al., 2005; Bayramoglu et al., 2006; EL-Sherif et al., 2008; Parameswari et al., 2009; Al Garni et al., 2009).

Sorption isotherms of the typical Langmuir adsorption pattern were applied in different studies concerning removal of cadmium from aqueous solution (Liu et al., 2006; El-Morsy, 2004; Babarinde et al., 2008). The sorption process involves biomass as a solid phase and a liquid phase containing metal ions, with ion distribution between solid and liquid phases determined by the affinity of biomass for metals. The quality of the biosorbent material is evaluated in terms of how much metal it can attract and retain in an immobilized form. Results of the present study are consistent with the
Langmuir isotherm model (Fourest and Roux, 1992).

Living biomass was more efficient as biosorbent for cadmium (II) compared to its dried biomass. This was in accordance with that reported by Al-Garni et al. (2009). Conversely other results reported the success of the dried biomass in removal of cadmium from an aqueous solution (Volesky, 1990; Zhou and Kiff, 1991; Bayramoglu et al., 2006). The biosorption by the two forms was dependent on the fungal species and maybe on its strains. These may be due to the differences between the mechanism of biosorption in both living and dead biomass in addition to low density, poor mechanical strength and little rigidity of the dried form (Leusch et al., 1995).

Immobilization using both adsorption and entrapment techniques were applied for biosorption of heavy metals from aqueous solution (Rani et al., 2010). The present study indicates the fail of the luffa adsorbed fugal biomass in removal of cadmium (II) from the waste water. Our results are supported by that reported by Gourdon et al. (1990) and lqbal et al. (2007). This difference in the behavior depends on individual characteristics of each fungus and on different factors; the support may possesses poor mechanical stability as reported by Klooster and Lilly (1985). The present study indicates that $A$. cristatus can be used as an efficient living biosorbent for removal of $\mathrm{Cd}(\mathrm{II})$ from wastewater.

\section{ACKNOWLEDGEMENTS}

The authors wish to express their grateful thanks to Professor: Sawsan Aboul Ezz and Professor: Ahmed M. El- Nemr, National Institute of Oceanography and fisheries, for their kind help, and valuable proof revision the article. 


\section{REFERENCES}

Abu Al-Rub FA, El-Naas MH, Benyahia F, Ashour FI (2004). Biosorption of nickel on blank alginate beads, free and immobilized algal cells. Process Biochem. 39: 1767-1773.

Akthar MN, Sastry KS, Mohan PM (1996). Mechanism of metal ion biosorbtion by processed Aspergillus niger biomass. Biometals. 9: 21-28.

Akthar MN, Mohan PM (1995). Bioremediation of toxic metal ions from polluted lake waters and industrial effluents by fungal biosorbent. Curr Sci. 69:1028 - 1030.

Al-Garni SM (2005). Biosorption of lead by Gram-ve capsulated and non- capsulated bacteria. Water SA. 31: 345-350.

Al-Garni SM, Ghanem KM, Bahobail SA (2009). Biosorption characteristics of Aspergillus fumigatus in removal of cadmium from an aqueous solution. African Journal of Biotechnology. 8: 4163-4172.

Babarinde NA, Oyebamiji Babalola JK, Adegbo A (2008).Kinetic, Isotherm and Thermodynamic Studies of the Biosorption of Cadmium (II) by Snail (Lymnaea rufescens) Shell. Journal of Applied Sciences Research. 4: 1420-1427.

Bayramoglu G, Tuzun I, Celik G, Yilmaz MN, Arica MY (2006). Biosorption of mercury (II), cadmium (II) and lead (II) ions from aqueous system by microalgae Chlamydomonas reinhardtii immobilized in alginate beads. Int. J. Mineral Processing. 81: 35-43.

Bozzola JJ, Russell LD (1999). Electron Microscopy: Principles and Techniques for Biologists. $2^{\text {nd }}$ ed., Jones and Bartlett Publishers, Massachusetts, USA.

Budavari SO, Neil MJ, Smith A (1989). The Merck index, An Encyclopedia of Chemical, Drugs, and Biologicals. Merck \&Co., INC. Rahway, N.J., U.S.A

Cochran WG, Snedecor GW (1989). Statistical Methods. P.466. Lowa State University Press, Ames, Lowa 50014

Diels L , Van der Lelie N, Bastiaens L (2002). New development in treatment of heavy metal contaminated soils. Rev. Environ. Sci. Biotechnol. 1: 75-82.

El-Helow ER, Sabry SA, Amer RM (2000). Cadmuim biosorption by a cadmuim resistant strain of bacillus thuringiensis: Regulation and optimization of cell surface affinity for metal cations. BioMetals.13: $273-280$.

El-Morsy E (2004). Cunninghamella echinulata a new biosorbent of metal ions from polluted water in Egypt. Mycologia. 96: 1183-1189.

El-Sersy NA, El-Sharouny EE (2007). Nickel biosorption by free and immobilized cells of marine Bacillus subtilis N10. Biotechnology. 6: 316-321.

El-Sherif IY, Ashmawy A, Badr S (2008). Biosorption of cadmium and nickel by Nile algae. J. Appl. Sci. Res. 4(4): 391-396.

Fourest E, Roux JC (1992). Heavy metal biosorption by fungal mycelial by-products: mechanisms and influence of $\mathrm{pH}$. Appl Microbiol Biotechnol. 3:399-403.

Gadd GM (1992). Microbial control of heavy metal pollution. In Microbial Control of Pollution, (eds. Fry JC, Gadd GM, Herbert RA, Jones CW and Watson IA). pp. 59-88. Cambridge: Cambridge University Press.

Ghanem NB , Abou - Elela JM (2006). Copper uptake from aqueous solution by free and immobilized cells of marine Nocardiopsis aegyptica sp. Nov., Assuit Univ. J.Bot. 35:259 - 273.

Gourdon R, Bhande S, Rus E , Sofer SS (1990). Comparison of cadmium biosorption by gram positive and gram negative bacteria from activated sludge. Biotechnol. Lett. 12: 839-842.

Guangyu Y, Thiruvenkatachar V (2003). Heavy metals removal from aqueous solution by fungus Mucor rouxii. Water Res. 37: 4486-4496.

Herrero R, Lodeiro P, Ray-Castro C, Vilarino T, Manuel E (2005). Removal of inorganic mercury from aqueous solution by biomass of the marine macroalgae Cystoseira baccata. Water Res. 39: 31993210.

Huang C, Huang P (1996). Application of Aspergillus oryze and Rhizopus oryzae for Cu(II) removal. Water Research. 30: 1985-990.

Igwe JC, Abia AA (2006). A bioseparation process for removing heavy metals from waste water using biosorbents. Afr. J. Biotechnol. 5: 1167-1179.

lqbal M, Saeed A, Zafar SI (2007). An innovative matrix to enhance the biosorption of $\mathrm{Cd}$ (II) from aqueous solution, Journal of Hazardous Materials. 148: 47-55.
Kacar Y, Arpa C, Tan S, Denizli A, Genc O, Arica MY(2000). Biosorption of $\mathrm{Hg}$ (II) and Cd (II) from aqueous solution: Comparison of biosorptive capacity of alginate and immobilized live and heat inactivated Phanerochaete chrysosporium. Process Biochem. 37: 601-610.

Kapoor A, Viraraghavan T (1995).Fungal biosorption-an alternative treatment option for heavy metal bearing wastewater: a review. Biores Technol. 53: 195-206.

Klooster J, Lilly MD (1985). An air loop reactor for the transformation of steroids by immobilized cells.Biotech.Lett. 7: 25-30.

Leusch A, Holan ZR, Volesky BJ (1995). Biosorption of heavy metals in water supplies production of oil industry. J. Chem. Technol. Biotechnol. 62: 279-288.

Liu Y G, Fan T, Zeng G M, Li X, Tong Q, Ye F, Zhou M, Xu W H, Huang $Y E$ ( 2006) Transactions of Nonferrous Metals Society of China. 16:681-686.

Lodeiro P, Barriada JL, Herrero R, Sastre de Vicente ME (2006). The marine macroalga Cystoseira baccata as biosorbent for cadmium(II) and lead(II) removal: kinetic and equilibrium studies. Environ. Pollut. 142: 264-273.

Mashitah MD, Yus Azila Y, Bhatia S (2008). Biosorption of cadmium (II) ions by immobilized cells of Pycnoporus sanguineus form aqueous solution. Bioresour. Technol. 99: 4742-4748.

Parameswari E, Lakshmanan A, Thilagavathi T (2009). Biosorption of cadmium and nickel(II) by bacterial isolates from an aqueous solution. Electronic J. Environ. Agric. Food Chem. 8: 150-156.

Park D, Yun YS, Park JM (2005). Use of dead fungal biomass for the detoxification of hexavalent chromium: screening and kinetics. Process Biochem. 40: 2559-65.

Pinghe Y, Qiming, Y, Bo J, Zhao L (1999). Biosorption removal of cadmium from aqueous solution by using pretreated fungal biomass cultured from starch wastewater. Water Res. 33: 1960-1963.

Plackett RL, Burman JP (1946). The design of optimum multifactorial experiments. Biometrica. 33: 305-325.

Rani M, Hemambika B, Hemapriya J, Rajesh Kannan V (2010). Comparative assessment of heavy metal removal by immobilized and dead bacterial cells: A biosorption Approach. African Journal of Environmental Science and Technology. 4: 077-083.

Raper KB, Fennell DI (1965). The genus Aspergillus. The Williams and Wilkins Company Baltimore: pp. 160-172.

Rao KR, Rashmi K, Latha J, Mohan P M (2005). Bioremediation of toxic metal ions using biomass of Aspergillus fumigatus from fermentative waste. Indian Journal of Biotechnology. 4: $139-143$.

Rostami K, Joodaki MR (2002). Some studies of cadmium adsorption using Aspergillus niger, Penicillium austurianum, employing an airlift fermenter. Chem Eng J. 89: 239-52.

Saglam N, Say R, Denizli A, Patir S, Yakup Arica M (1999). Biosorption of inorganic mercury and alkylmercury species on to by Phanerochaete chrysosporium mycelium. Process Biochem. 34: 725 - 730.

Say R, Yilmaz N, Denizli A (2003). Biosorption of cadmium, lead, mercury, and arsenic ions by the fungus Penicillium purpurogenum. Separation Sci. Technol. 38: 2039-2053.

Singh AN, Zeng DH, Chen FS (2005). Heavy metal concentrations in redeveloping soil of mine spoil under plantations of certain native woody species in dry tropical environment, India. J. Environ. Sci. A. N. Singh. 17: 168.

Svecova L, Spanelova M, Kubal M, Guibal E (2006). Cadmium, lead and mercury biosorption on waste fungal biomass issued from fermentation industry. I. Equilibrium studies. Separation Purification Technol. 52(1): 142-153.

Tangaromsuk J, Pokethitiyook P, Kruatrachue M, Upatham ES (2002). Cadmium biosorption by Sphingomonas paucimobitis biomass Bioresour. Technol. 85: 103-105.

Tilaki RA, Hahvi AH, Shariat M, Nasseri S (2004). Study of cadmium removal from environmental water by biofilm covered granular activated carbon. Iranian J. Public Health. 33(4): 43-52.

Vala AK (2010). Tolerance and removal of arsenic by a facultative marine fungus Aspergillus candidus. Bioresource Technology. 101(7): 2565-2567.

Vankar P, Bajpa D (2008). Phyto-remediation of chrome-VI of tannery effluent by Trichoderma species. Desalination, 222: 255-262. 
Volesky B (1990). Biosorption of heavy metals.CRC. Press, Boca Raton,p. 429.

Volesky B (1994). Advances in biosorption of metals: selection of biomass Types. FEMS Microbial Rev. 14: 291-302.

Volesky B, May-Phillips H A (1995). Biosorption of heavy metals by Saccharomyces cerevisiae. Biotechnol. Bioeng. 41: 826 829.Volesky B, Holan Z (1995). Biosorption of heavy metals. Biotechnology Progress, 11: 235-250.

Watanabe T (2002). Pictorial atlas of soil and seed fungi. CRC Press, 2nd ed. pp. 190-196.

Wang J L, Chen C (2006). Biosorption of heavy metals by Saccharomyces cerevisiae: a review. Biotechnol Adv. 24: 427-451.

Wang J, Chen C (2009). Biosorbents for heavy metals removal and their future Biotechnology Advances, 27: 195-226.
Yan G, Viraraghavan T (2003). Heavy-metal removal from aqueous solution by fungus Mucor rouxii, Water Research, 37: 4486-4496.

Yalcinkaya Y, Arica MY, Soysal L, Denizli A, Genc O, Bektas S (2002). Cadmium and mercury uptake by immobilized Pleurotus sapidus. Turk. J. Chem. 26: 441-452.

Zamil SS, Ahmad S, Choi MH, Park JY, Yoon SC (2009). Correlating metal ionic characteristics with biosorption capacity of Staphylococcus saprophyticus BMSZ 711using QICAR model. Bioresour. Technol. 100: 1895-1902.

Zhou JL, Kiff RJ (1991). The uptake of copper from aqueous solution by immobilized fungal biomass. J. Chem. Technol. Biotechnol. 52: 317330. 